\title{
ASSESSMENT OF ATMOSPHERIC METAL DEPOSITIONS IN THE INDUSTRIAL AREAS OF THE SOUTHWEST OF NIGERIA.
}

FATOBA, P. O., *OGUNKUNLE, C. O. and OLAWEPO, G. K.

DOI:http://dx.doi.org/10.4314/ejesm.v5i3.7

Received 28th March 2012; accepted 17th May 2012

\begin{abstract}
Industrial wastes and discharges have been reported to cause environmental pollution. Lagos and Ogun states house many industries which are assumed to have impacted the states. It is in respect of these that the atmospheric metal deposit of Lagos and Ogun industrial areas, southwest Nigeria were assessed to determine the extent of air pollution of these areas. 100 moss samples were collected from the industrial areas of these two states and were digested using Nordic guidelines and the $\mathrm{As}, \mathrm{Cd}, \mathrm{Cr}, \mathrm{Pb}, \mathrm{Ni}, \mathrm{Cu}$ and $\mathrm{Ag}$ contents determined by Atomic Absorption Spectrophotometeric method. Data generated were statistically analysed with Analysis of Variance and the means separated with Duncan Multiple Range Test. It was found that Ogun state was more polluted with $\mathrm{Cd}$, Ni and $\mathrm{Cu}$, Lagos state had more of $\mathrm{Pb}$ while the $\mathrm{Cr}$, $\mathrm{Ag}$ and As concentrations of the two areas were statistically the same. Moreover, the concentrations of $\mathrm{Ag}$, As and $\mathrm{Cr}$ were less than $1 \mathrm{mg} / \mathrm{I}$ while those of $\mathrm{Cd}, \mathrm{Cu}, \mathrm{Ni}$ and $\mathrm{Pb}$ were less than $10 \mathrm{mg} / \mathrm{l}$. These metals contributed differently to the pollution of the study areas. It was further found that the highest concentrations of $\mathrm{Pb}(9.16 \mathrm{mg} / \mathrm{l}), \mathrm{Ag}(0.07 \mathrm{mg} / \mathrm{l}), \mathrm{Cr}(0.32 \mathrm{mg} / \mathrm{I})$ were found in Mile 2, Ojota and Mile 2 respectively in Lagos while the least concentrations were found in Aiyepe, Ogun state. In the same vein, the highest concentration of As $(0.31 \mathrm{mg} / \mathrm{l})$, Ni $(98.32 \mathrm{mg} / \mathrm{l}), \mathrm{Cu}(7.76 \mathrm{mg} / \mathrm{I})$ and $\mathrm{Cd}(8.70 \mathrm{mg} / \mathrm{l})$ were recorded in Agbara, Attan-tta, Sagamu and Aiyepe respectively, all in Ogun state. The least values were found in Aiyepe $(0.04 \mathrm{mg} / \mathrm{l})$, Ikeja $(6.54 \mathrm{mg} / \mathrm{l})$, Mile $2(5.83 \mathrm{mg} / \mathrm{l})$ and Ojota $(1.85 \mathrm{mg} / \mathrm{ll})$ respectively. However, all these heavy metals were present in concentrations greater than the recommended limits of Federal Environmental Protection Agency and European Communities and this suggest that the study areas are highly polluted. It is hoped that the results of this study would inform the Government and the citizens of the study areas that their environments are polluted with heavy metals. This would certainly help in taking proactive steps that will help to reduce the pollution load.
\end{abstract}

Keywords: Air quality, biomonitors, anthropogenic, environment, passive biomonitoring, exudates

\section{Introduction}

The quality of our environment is a matter of urgent and serious concern, especially now that the consequences of human interventions are already evident. Although environment is extremely valuable to people and other organisms living in it, it is also endangered due to human activities that are continuously deteriorating it (Davis, 2006). Metals that used to exist in traces in the environment due to natural sources have become ubiquitous and hazardous these days due to the extreme human/anthropogenic contributions. Many of them are usually extracted, purified and processed for industrial use and then released again into the environment (Davis, 2006).
The direct measurements of air quality provide objective information about the level of pollutants but are expensive and risks of contamination at low concentrations is high (Ruta and Dainius, 2010). However, the use of biomonitors has been highly adopted these days because it provides information on both the quantity of pollutants and their effects on the occurrence and condition of biomonitors. Biomonitoring using bioindicators has become a potentially effective and economical alternative to the direct ambient air measurements. The use of mosses to monitor environmental changes due to pollutants has been advocated by several researchers.

Department of Plant Biology. University of Ilorin,

P. M. B. 1515, Ilorin, Nigeria

*Corresponding author email:

ogunkunle.co@unilorin.edu.ng; 
Rackley (2010) opined that mosses are ideal for monitoring trends in the deposition of pollutants over time and across difference places. Data on prevalence of mosses provide a better geographic coverage of atmospheric pollution at a local level than measured deposition data (Rackley, 2010).

Chakrabortty and Paratkar (2006) asserted that biomonitoring is a very important method for source identification of air pollutant and the ease of sampling; the absence of any need for complicated an expensive technical equipment has made it widely accepted. The accumulative and time-integrative behavior of the moss biomonitor give biomonitoring of air quality advantages for its continuing practice even in large-scaled surveys (Chakrabortty and Paratkar, 2006). Biomonitoring also offers the benefit of predicting suitable moss species that may be used as a biomonitor for a single trace element, or a group of trace elements.

Lagos state happens to be Africa's second most populous city with population of 14.4 million in 2002 and projected to be over 20 million in 2010 (Olowoporoku, 2007). It is responsible for over $70 \%$ of the nation's commercial and industrial activities while Ogun state has about 138 industrial establishments that generate 5,479 tons of waste per year (FEPA, 1996). The population coupled with intense industrial and commercial activities in these states must have impacted the environment.

This paper therefore tends to assess the particulate metals deposition around Lagos and Ogun states, Southwest Nigeria by passive biomonitoring of the concentrations of elemental pollutants with the use of mosses.

\section{Materials and Methods \\ Study Area}

Lagos state $\left(6^{\circ} 27^{1} \mathrm{~N} ; 3^{\circ} 34^{1} \mathrm{E}\right)$ is Africa's second most populous city of average population density of 20,000 person $/ \mathrm{km}^{2}$ (Olowoporoku, 2007). Ogun state $\left(6^{\circ} 70^{1} \mathrm{~N} ; 3^{\circ}\right.$ $23^{1} \mathrm{E}$ ) has about 158 industrial establishments that generate 5,470 tons of solid waste per year (FEPA, 1996).

\section{Sampling}

Ectohydric moss samples were collected from industrial areas in Lagos (Marina, Ojota, Mile 2, Oshodi, Ikeja and Apapa) and Ogun states (Sagamu, Sango-otta, Agbara and Attanotta); the high class residential area (Victoria Island) served as the Control site for Lagos and semi-rural area of Ogun (Aiyepe) served as the Control. Minimum of six (6) moss samples were randomly collected in each location depending on its availability between November and December, 2011. Samplings were carried out according to the Nordic guidelines (Kubin et al., 2000) and the digestion procedure followed the method of Jozwiak and Jozwiak (2009). Atomic Absorption Spectrophotometric method was employed to determine the concentrations of $\mathrm{As}, \mathrm{Cd}, \mathrm{Cr}, \mathrm{Pb}, \mathrm{Ni}, \mathrm{Cu}$ and $\mathrm{Ag}$. For quality control, Certified Reference Material-IAEA 336 was used and the percentage recoveries of the heavy metals were within the range stipulated. The data generated from the quantification were subjected to Analysis of Variance to compare the means and means that were significantly different were separated with the use of Duncan Multiple Range Test 


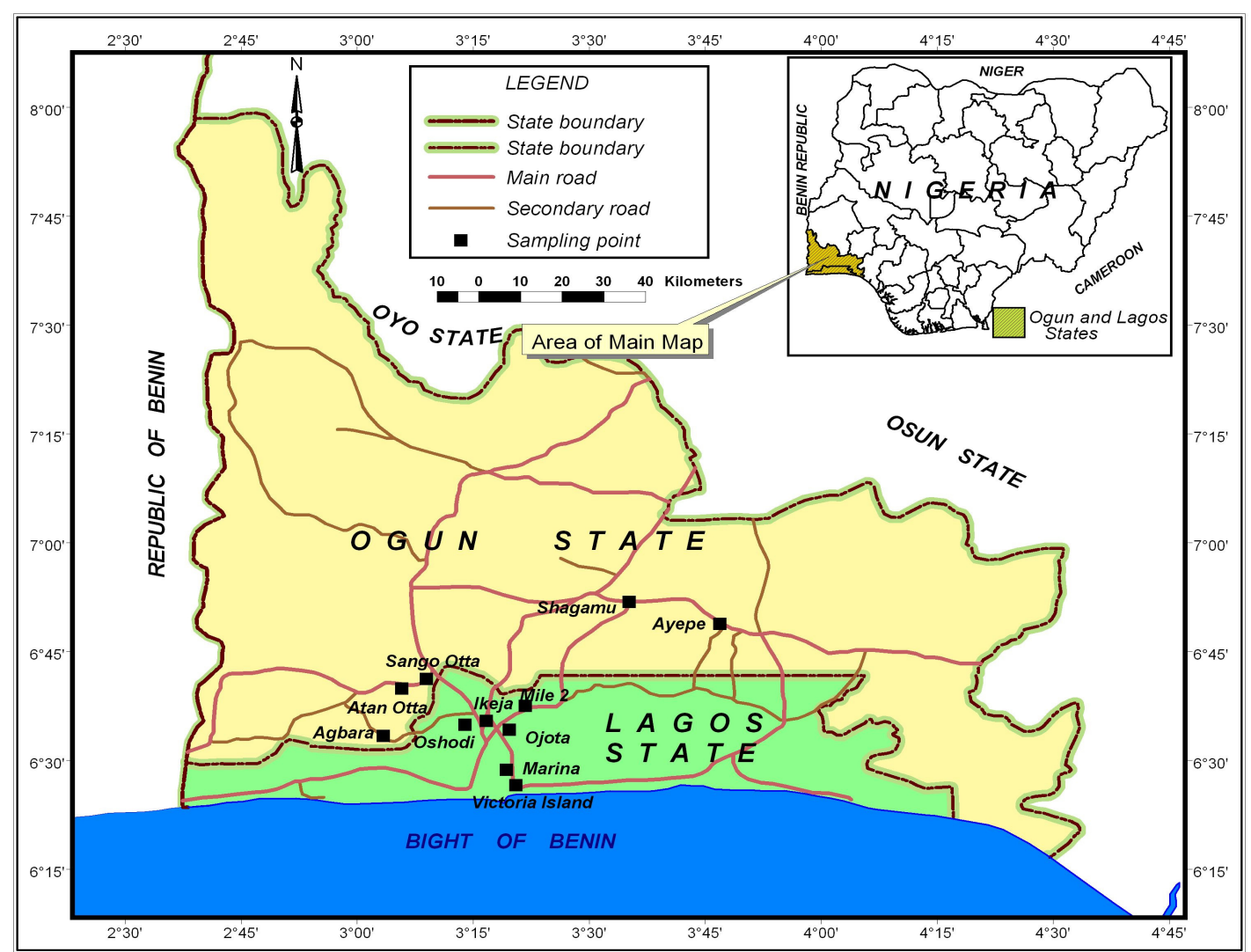

Figure 1 Map of study area showing sampling points in the two states

\section{Results}

Table 1 shows the heavy metal depositions in Lagos state. Table 1 shows that $\mathrm{Cr}, \mathrm{Ag}$ and As were less than $1 \mathrm{mg} / \mathrm{l}$ in this area while $\mathrm{Cd}$, $\mathrm{Pb}, \mathrm{Ni}$ and $\mathrm{Cu}$ were less than $10 \mathrm{mg} / \mathrm{l}$. This trend is also true of Ogun state (Table 2). Aiyepe which happened to be the Control for Ogun State had the greatest amount of $\mathrm{Cd}$ $(8.70 \mathrm{mg} / \mathrm{l})$ while the least concentration was found at Ojota $(1.85 \mathrm{mg} / \mathrm{l})($ Table 1$)$. The trend of contaminations of the locations is thus: Aiyepe $>$ Agbara $>$ Sagamu $>$ Sango otta $>$ Apapa $>$ Ikeja $>$ Attan otta $>$ Marina $>$ Victoria island $>$ Oshodi $>$ Mile $2>$ Ojota $>$ (Tables $1 \& 2$ ). The trend shows that Ogun state was more polluted with cadmium than Lagos state. When the values were statistically tested, it was found that $\mathrm{Cd}$ concentration of Aiyepe, Agbara, Sagamu, Sango otta were statistically the same; Apapa, Ikeja and Attan otta statistically the same, Mile 2 and Oshodi statisistically the same but all were statistically greater than Ojota at $\mathrm{P} \leq 0.05$

The highest mean concentration of chromium in Lagos state was found at Mile 2 $(0.32 \mathrm{mg} / \mathrm{l})$ followed by Victoria Island $(0.29 \mathrm{mg} / \mathrm{l})$ while Marina had the least concentration $(0.13 \mathrm{mg} / \mathrm{l})$ (Table 1$)$. Table 2 also shows that chromium was highest at Aiyepe and least at Sango otta. Statistically, $\mathrm{Cr}$ was found to have equal influence on the pollution status of the twelve locations though very low in concentrations. The mean value of Cr was found to be statistically the same all through the study areas at $\mathrm{P} \leq 0.05$ but numerically different.

In Lagos state, the concentrations of $\mathrm{Ni}$ ranged between $6.54 \mathrm{mg} / \mathrm{l}$ and $8.20 \mathrm{mg} / \mathrm{l}$ while it was between $6.95 \mathrm{mg} / \mathrm{l}$ and $8.32 \mathrm{mg} / \mathrm{l}$ in Ogun state. Although, Ogun state seems to have higher values than Lagos state but both states had the same concentrations of $\mathrm{Ni}$ statistically at $\mathrm{P} \leq$ 
0.05. This shows that $\mathrm{Ni}$ exerts the same influence on the atmosphere of all the studied locations.

Attan otta (Ogun state) had the highest $\mathrm{Ni}$ mean concentration and Ikeja (Lagos state) had the least $(6.54 \mathrm{mg} / \mathrm{l})($ Tables $1 \& 2)$. Nickel was grossly abundant in all the locations and its concentrations were found to be statistically the same at $\mathrm{P} \leq 0.05$.

The concentrations of $\mathrm{Cu}$ in Agbara and Sagamu were numerically greater but statistically the same with other locations that were statistically the same but greater than Mile 2 at $\mathrm{P} \leq 0.05$. Highest $\mathrm{Cu}$ mean value $(7.76 \mathrm{mg} / \mathrm{l})$ was got in Sagamu (Ogun state) and Mile 2 had the least $(5.83 \mathrm{mg} / \mathrm{l})$ (Lagos state) (Tables 1\&2). It was found that when the mean concentrations of $\mathrm{Cu}$ were subjected to statistical analysis, $\mathrm{Cu}$ had approximately equal contribution to the pollution of all the locations except Mile 2 that was lower. Copper was heavily abundant in all the locations and the trend of the concentrations is as follows numerically:

Sagamu $>$ Agbara $>$ Ikeja $>$ Oshodi $>$ Attanotta $>$ Marina $>$ Sangootta $>$ Aiyepe $>$ Ojota $>$ Victor ia island $>$ Apapa $>$ Mile 2 (Tables1\&2). Copper appeared to be more abundant in Ogun state than Lagos state, that is Ogun state is more $\mathrm{Cu}$ polluted than Lagos state.

Lead was highest in Mile $2(9.16 \mathrm{mg} / \mathrm{l})$ while Aiyepe had the least $(2.74 \mathrm{mg} / \mathrm{l})$. The mean values showed that lead contributed differently to the pollutions of all the locations; $\mathrm{Pb}$ concentrations significantly differed at $\mathrm{P} \leq$ 0.05 . Lagos state was highly polluted with lead, especially Mile 2, Ojota and Apapa (Table 1). The concentration trend is as follows: Mile 2 $>$ Ojota $>$ Apapa $>$ Ikeja $>$ Sango otta $>$ Oshodi $>$ Agbara $>$ Sagamu $>$ Victoria Island $>$ Marina $>$ Attan otta $>$ Aiyepe.

Silver was less than $0.1 \mathrm{mg} / \mathrm{l}$ in all the locations, suggesting a low contribution to the pollution status of the study areas. Ojota had the highest mean concentration of $\mathrm{Ag}$ $(0.07 \mathrm{mg} / \mathrm{l})$, followed by Oshodi $(0.07 \mathrm{mg} / \mathrm{l})$ and the least was found in Aiyepe $(0.02 \mathrm{mg} / \mathrm{l})$ (Tables 1\&2). Statistically, $\mathrm{Ag}$ contributed differently to the pollution of the 12 locations at $\mathrm{P} \leq 0.05$; there was equal influence on the pollution of Aiyepe, Sagamu, Attan otta, Victoria Island, Apapa, Marina while Mile 2, Sango otta, Agbara, Ikeja, Oshodi and Ojota were the same statistically. Generally, the environments of both Lagos and Ogun states were less impacted by Ag pollution.

Arsenic concentration was highest in Agbara $(0.31 \mathrm{mg} / \mathrm{l})$ and least at Aiyepe $(0.04 \mathrm{mg} / \mathrm{l})$. The environments of Lagos and Ogun states were less polluted with As and the mean concentrations at all the locations were the same at $\mathrm{P} \leq 0.05$ and less than $0.40 \mathrm{mg} / \mathrm{l}$. 
Table 1. Mean concentrations of the heavy metals $(\mathrm{mg} / \mathrm{l})$ at different locations of Lagos States

\begin{tabular}{|c|c|c|c|c|c|c|c|}
\hline \multirow[t]{2}{*}{ Location } & \multicolumn{7}{|c|}{ Concentrations (mg/l) } \\
\hline & $\mathrm{Cr}$ & $\mathrm{Cd}$ & $\mathrm{Ni}$ & $\mathrm{Cu}$ & $\mathrm{Pb}$ & $\mathrm{Ag}$ & As \\
\hline \multirow[t]{2}{*}{ Victoria island } & $0.29^{\mathrm{a}}$ & $2.62^{\mathrm{dc}}$ & $7.99^{\mathrm{a}}$ & $6.62^{\mathrm{ab}}$ & $3.49^{\text {bcd }}$ & $0.03^{\text {bcd }}$ & $0.11^{\mathrm{b}}$ \\
\hline & 0.3257 & 1.2574 & 0.7289 & 0.5590 & 0.6005 & 0.0213 & 0.0183 \\
\hline \multirow[t]{2}{*}{ Marina } & $0.13^{\mathrm{a}}$ & $2.75^{\mathrm{dc}}$ & $7.39^{\mathrm{a}}$ & $7.03^{\mathrm{ab}}$ & $3.19^{\mathrm{bcd}}$ & $0.04^{\text {bcd }}$ & $0.21^{\mathrm{ab}}$ \\
\hline & 0.0337 & 1.7329 & 0.6018 & 0.1144 & 1.2224 & 0.0050 & 0.0860 \\
\hline \multirow[t]{2}{*}{ Apapa } & $0.17^{\mathrm{a}}$ & $5.31^{\mathrm{bcd}}$ & $6.69^{\mathrm{a}}$ & $6.26^{\mathrm{ab}}$ & $6.62^{\mathrm{cd}}$ & $0.03^{\mathrm{bcd}}$ & $0.12^{\mathrm{b}}$ \\
\hline & 0.0424 & 0.9612 & 0.4389 & 0.6390 & 4.1804 & 0.0050 & 0.0150 \\
\hline \multirow[t]{2}{*}{ Ikeja } & $0.25^{\mathrm{a}}$ & $4.80^{\text {bcde }}$ & $6.54^{\mathrm{a}}$ & $7.36^{\mathrm{ab}}$ & $5.68^{\mathrm{bcd}}$ & $0.06^{\mathrm{ab}}$ & $0.12^{\mathrm{b}}$ \\
\hline & 0.1112 & 2.3043 & 0.5597 & 0.5881 & 2.1621 & 0.0191 & 0.0424 \\
\hline \multirow[t]{2}{*}{ Oshodi } & $0.28^{\mathrm{a}}$ & $2.61^{\mathrm{de}}$ & $7.97^{\mathrm{a}}$ & $7.17^{\mathrm{ab}}$ & $4.81^{\mathrm{bcd}}$ & $0.07^{\mathrm{a}}$ & $0.17^{\mathrm{ab}}$ \\
\hline & 0.1322 & 0.9411 & 1.774 & 0.7024 & 1.3590 & 0.0091 & 0.1296 \\
\hline \multirow[t]{2}{*}{ Ojota } & $0.24^{\mathrm{a}}$ & $1.85^{\mathrm{e}}$ & $8.01^{\mathrm{a}}$ & $6.76^{\mathrm{ab}}$ & $6.63^{\mathrm{bcd}}$ & $0.07^{\mathrm{a}}$ & $0.22^{\mathrm{ab}}$ \\
\hline & 0.1152 & 0.0949 & 0.4357 & 0.5406 & 1.4249 & 0.0244 & 0.1273 \\
\hline \multirow[t]{2}{*}{ Mile 2} & $0.32^{\mathrm{a}}$ & $2.23^{\mathrm{de}}$ & $8.20^{\mathrm{a}}$ & $5.83^{\mathrm{b}}$ & $9.16^{\mathrm{a}}$ & $0.05^{\mathrm{abc}}$ & $0.23^{\mathrm{ab}}$ \\
\hline & 0.2996 & 0.7562 & 0.9316 & 2.5667 & 1.6466 & 0.0244 & 0.0826 \\
\hline
\end{tabular}

Note: Values with same superscript in the same column are not significantly different at $\mathrm{P} \leq$ 0.05 .

Italicized values are standard deviations of the mean values.

Table 2. Mean concentrations of the heavy metals ( $\mathrm{mg} / \mathrm{l})$ at different locations of Ogun States

\section{Location}

\begin{tabular}{llllllll} 
& $\mathrm{Cr}$ & $\mathrm{Cd}$ & $\mathrm{Ni}$ & $\mathrm{Cu}$ & $\mathrm{Pb}$ & $\mathrm{Ag}$ & \multicolumn{1}{c}{$\mathrm{As}$} \\
\hline \multirow{2}{*}{ Aiyepe } & $0.27^{\mathrm{a}}$ & $8.70^{\mathrm{a}}$ & $7.34^{\mathrm{a}}$ & $6.86^{\mathrm{ab}}$ & $2.74^{\mathrm{d}}$ & $0.02^{\mathrm{d}}$ & $0.04^{\mathrm{a}}$ \\
& 0.0150 & 1.3473 & 2.0586 & 1.3123 & 1.4120 & 0.0046 & 0.0173 \\
& & & & & & & \\
Sagamu & $0.20^{\mathrm{a}}$ & $6.93^{\mathrm{ab}}$ & $6.95^{\mathrm{a}}$ & $7.76^{\mathrm{a}}$ & $3.67^{\mathrm{bcd}}$ & $0.03^{\mathrm{cd}}$ & $0.09^{\mathrm{b}}$ \\
& 0.0830 & 1.5646 & 1.2603 & 0.9365 & 1.3167 & 0.0093 & 0.0330 \\
& & & & & & & \\
Agbara & $0.24^{\mathrm{a}}$ & $7.65^{\mathrm{ab}}$ & $7.60^{\mathrm{a}}$ & $7.75^{\mathrm{a}}$ & $4.23^{\mathrm{bcd}}$ & $0.06^{\mathrm{ab}}$ & $0.31^{\mathrm{a}}$ \\
& 0.1100 & 3.8984 & 1.1611 & 1.3030 & 1.5983 & 0.0303 & 0.2958 \\
Sango otta & $0.14^{\mathrm{a}}$ & $6.63^{\mathrm{abc}}$ & $7.97^{\mathrm{a}}$ & $7.00^{\mathrm{ab}}$ & $5.15^{\mathrm{bcd}}$ & $0.05^{\mathrm{abc}}$ & $0.16^{\mathrm{ab}}$ \\
& 0.09881 & 3.2047 & 1.0155 & 0.8511 & 2.6529 & 0.0282 & 0.1310 \\
& & & & & & & \\
Attan otta & $0.23^{\mathrm{a}}$ & $3.77^{\mathrm{cde}}$ & $8.32^{\mathrm{a}}$ & $7.10^{\mathrm{ab}}$ & $3.16^{\mathrm{cd}}$ & $0.03^{\mathrm{cd}}$ & $0.11^{\mathrm{b}}$ \\
& 0.0141 & 1.6986 & 0.8513 & 0.8487 & 0.8536 & 0.0118 & 0.0082 \\
& & & & & & & \\
\hline
\end{tabular}

Note: Values with same superscript in the same column are not significantly different at $\mathrm{P} \leq$ 0.05 .

Italicized values are standard deviations of the mean values. 


\section{Discussion}

Heavy metal concentrations vary in moss samples depending on environmental impact (Chipev and Kovachev, 2006); uptake characteristics of particular species of moss and the availability of the metal ions in the surrounding environment (Ross, 1994). The elemental patterns in mosses reflected atmospheric deposition patterns (Cunny et al., 2001). Preponderance of $\mathrm{Pb}, \mathrm{Cu}, \mathrm{Cd}, \mathrm{Ni}$, and $\mathrm{Cr}$ were observed in all the locations and this could be linked to the loading of petroleum products in Sagamu and Apapa, emissions from industrial estates of Mile 2, Sango otta, Oshodi, Agbara and Ikeja and vehicular emissions in Victoria Island, Ojota and Marina. High concentrations of these metals denote heavy air pollution in the areas of Lagos and Ogun states.

The high cadmium concentration detected indicates the ubiquity of this toxic metal in the environment and shows that the areas are cadmium-polluted. According to Federal Environmental Protection Agency (1988), European Communities (2001) and World Health Organization (2000), the recommended atmospheric limit for $\mathrm{Cd}$ are $0.003 \mathrm{mg} / \mathrm{l}, 5 \mathrm{ng} / \mathrm{l}$, and $0.02 \mathrm{mg} / \mathrm{l}$ respectively and these values are far below the concentrations got in the study areas. $\mathrm{Cd}$ in the environment in low concentration could be from natural sources but the other probable sources of $\mathrm{Cd}$ in this study may be through anthropogenic activities. Awofolu (2005) puts forward that the largest source of $\mathrm{Cd}$ release to the environment is from industrial activities, burning of fossil fuels and incineration of municipal waste materials. This assertion was also supported by Olowoyo and van Heerden (2010) that $\mathrm{Cd}$ in the environment is traced to urban metal smelting companies, burning of household wastes and paint manufacturing industries while Scerbo et al. (2010) mentioned that $\mathrm{Cd}$ in the environment is traced to Di-methyl cadmium used in the production of tetraethyl lead and it is emitted by vehicles. The presence of industries and several combustion processes like the car emissions contributed to the atmospheric $\mathrm{Cd}$ in the study. The high concentration of $\mathrm{Cd}$ in the Control of Ogun state (Aiyepe) could be from natural source coupled with acidification that increased the availability as supported by World Bank Group (1998). Vegetation exudates and forest fires could also be culprits as confirmed by EC (2001) that $25 \%$ of natural $\mathrm{Cd}$ emission is estimated to come from vegetation as exudates and slough.

Main natural source of airborne chromium are forest fires and probably eruptions (EPAQS, 2008). This is rare in these states and could not probably be responsible for the little amounts found in this study. It is evident that the low concentrations of $\mathrm{Cr}$ in this study were anthropogenic either through combustion or earth movement activities but still higher than the recommended FEPA atmospheric limit for Nigeria $(0.001 \mathrm{mg} / \mathrm{l})$ (FEPA, 1988).

Nickel is emitted through combustion of plants as nickel sulfate and oxidic nickel (EC, 2001). Nickel was highly abundant in this study and it is a fact that the introduction into the environment was man-made. The wide range of trade involving using/repairing components or devices containing $\mathrm{Ni}$ or its alloys especially stainless steel (alloy wheel in cars) has apparently increased its concentrations in the environment. Incineration of municipal garbage and sewage sludge has also been confirmed to account for $\mathrm{Ni}$ existence in the environment. The findings of Steinberger et al. (1994) confirmed the fact that $35-52 \%$ of $\mathrm{Ni}$ exists as fly ash from incinerated sludge. The rate of smoking these days in the urban has also contributed to the high Ni concentration. WHO (2000) asserted that mainstream cigarette smoke contains $0.04-$ $0.58 \mathrm{microgramsNi} /$ cigarette and consuming 20 cigarette/day will increase the ambient $\mathrm{Ni}$ value by 15 times. It is possible that the high population of smokers in Nigeria has added to Ni pollution because the concentrations in the study areas are far greater than the recommended WHO guidelines for air quality which is between 1-180 $\mathrm{g} / \mathrm{l}$ (WHO, 2000).

Copper in the environment is attributed to vehicular emissions/oil combustion and resuspended road dust (Farmaki and Thomaidis, 2008). Wang et al. (2009) also related the presence of copper to chemical industries and intensive traffics. The high emissions of vehicles, often old richety vehicles and 
abundance of industries in the study areas accounted for the high level of copper. Olowoporoku (2007) reported that $40 \%$ of all new vehicles registration in Nigeria is made in Nigeria and this accounts for about $40 \%$ of the total national fuel consumption. There is also the possibility of wind dispersal of this metal from Lagos state into Ogun state since they are contiguous states.

Lead remains the major trace element in urban environment due to its long residence time in the environment (Olowoyo and van Herdeen, 2010). The high concentrations of $\mathrm{Pb}$ got in the study areas exceeded the FEPA and EC recommended limits of $0.005 \mathrm{mg} / 1$ and $0.5 \mu \mathrm{g} / \mathrm{l}$ respectively and this is noted to be always associated with high traffic density, Lagos and Ogun states consist of several urban cities with high traffic density which increase the availability of $\mathrm{Pb}$ by release through the exhausts of motor vehicles. This signals that high levels of $\mathrm{Pb}$ are still released or resuspended by vehicle traffic (Odukoya et al., 2000). Scerbo et al. (2001) noted that vehicular emission seems to be the major source of atmospheric $\mathrm{Pb}$.

Most of man-made emissions of Arsenic stem from metal smelters which is emitted in form of arsenites or arsenates whereas natural sources are from volcanic activities (EC, 2001). These activities are rare in the study areas and this explains the low concentration of As in the environment.

Generally, the variations in concentrations of metals in Lagos and Ogun states is very insignificant, probably because these metals are always airborne and can be transferred from one state to another within little time frame. The closeness of the states also may account for little variation in the concentrations of the metals.

\section{References}

Awofolu, O.R. (2005), A survey of trace metals in vegetation, soil and lower animal along some selected major roads in metropolitan city of Lagos.- Environmental Monitoring and Assessment 105:431-447

Chakrabortty, S., Paratkar, G.T. (2006), Biomonitoring of trace element air pollution using mosses.- Aerosol and Air Quality Research. 6(2): 247-258.

Chipev, N., Kovachev A. (2006), Preliminary data on heavy metal contents in lichens from the Livingston Island. -Bulgarian Antarctic Research 2:106-109

Cunny, D., van Haluwyn, C., Pesch, R. (2001), Biomonitoring of trace elements in air and soil compartments along the major motorways in France. -Water, Air, Soil Poll. 125:273

Davis, E.B. (2006), Trends in environment research. - New York, USA. Nova Science

Publishers

European Communities. (2001), Ambient air pollution by $\mathrm{As}, \mathrm{Cd}$ and $\mathrm{Ni}$ compound.Official

Publications of the European Communities 10318

Expert Panel on Air Quality Standard. (2008), Guidelines for metals and metalloids in ambient air for the protection of human health.- Department of Environment, Food and Rural Affairs, London UK. http://www.defra.gov.uk/corporate/consult/met als-metalloids/

Farmaki, E.G., Thomaidis, N.S. (2008), Current status of the metal pollution of the environment of Greece- a review.- Global Nest 10(3): 366-375

Federal Environmental Protection Agency. (1996), Towards an environment action plan for

Ogun State.- World Bank Assisted Project, draft Final Report, 52-54

Federal Environmental Protection Agency. (1988), Guidelines and Standards for Environmental pollution control in Nigeria. Decree No 58 of 1988.- Federal Government of Nigeria.

Jozwiak, M. A., Jozwiak, M. 2009.Influence of cement industry on accumulation of heavy metals in bioindicators. Ecological Chemistry and Engineering, 16(3):323-334

Kubin, E., Lippo, H., Poikolainen, J. (2000), Heavy metal loading. In: Mälkönen E (ed)Forest condition in a changing environment - The Finnish Case.- Forestry Sciences 65; Kluwer Academic Publishers, Dordrecht, PP 60-71.

Odukoya, O.O., Arowolo, T.A., Bamgbose, O. (2000), $\mathrm{Pb}, \mathrm{Zn}$ and $\mathrm{Cu}$ levels in tree barks as 
indicator of atmospheric pollution.- Environ. Int. 26:11-16

Olowoporoku, D. (2007), Air quality management in Lagos. UWE, Bristol.- Air Quality

Management Resource Centre 1-33

Olowoyo, J.O., van Heerden, E. (2010), Trace element concentrations from lichen transplants in Pretoria, South Africa.- Envirn. Sci. Pollut. Res. DOI 10.1007/s11356-010-0410-3

Ross, E. K.(1994), Bryophyte plant physiology. http://IIkoning,escu.edu/plant/biology/magnifm os.html

Ruta, B., Dainius, P. (2010), Research into heavy metals pollution of Atmosphere applying moss as biomonitors: a literature review.- Environmental Research, Engineering and Management, 4(54): 26-33.

Scerbo, R., Ristori, T., Possenti, L., Lampugnami, L., Barale, R., Barghigiani, C. (2001), Lichen (Xanthoria parientina) biomonitoring of trace element contamination and air quality assessment in Pisa Province, Italy. Sci. -Total Environ. 286:27-40

Wang, Z.M., Song, K.S., Zhang, B., Liu, D.W., Ran, C.Y., Zhang, S.M., Luo, L., Zhang, C.H. (2009), Spatial variability and affecting factors of soil nutrients in cropsland of Northeast China.- Plant, Soil and Plant 55: 110-120

World Health Organization. (2000), Air quality guidelines for Europe.- WHO Regional Publication, European series No 91, Copenhagen.

World Bank Group. (1998), Cadmium. Pollution, Prevention and Abatement Handbook,

213-214

USEPA (2008), National ambient air quality standards for lead: final rule. www.epa.gov/ttn/naags/standards/pb/data/lead strategy/99/pdf. 